\title{
The Interdisciplinary Spiritual Care Model: A holistic Approach to Patient Care
}

\author{
O Modelo Interdisciplinar de Cuidado Espiritual: \\ Uma abordagem holística de cuidado ao paciente
}

\author{
René Hefti* \\ Mary Rute Gomes Esperandio**
}

\begin{abstract}
In the last two decades, studies on the relationship between spirituality and health have grown significantly in the International literature. In Brazil, the debate on this subject has reached greater visibility since 2009, mainly in the health sciences, with the appearance of the term "spiritual care". In theology, studies on spiritual care in the health care context are still scarce. This paper aims to contribute to the broadening of this reflection. Firstly, spiritual care is approached from scientific publications in Portuguese language. Second, the interdisciplinary spiritual care model is presented as a holistic approach to patient care and consequences of applying a spiritual care model are outlined. The newly defined role of the hospital chaplains, pastoral counselors and spiritual caregivers is also discussed. As a conclusion, the paper mentions the main challenges going along with interdisciplinary spiritual care, especially those concerning the training of health care professionals.
\end{abstract}

Keywords: spirituality; health care professionals; spiritual care; interdisciplinary; hospital chaplain

\section{Resumo}

Nas duas últimas décadas, os estudos sobre a relação entre espiritualidade e saúde tem crescido significativamente no cenário internacional. No Brasil, as pesquisas nesse campo ganharam maior visibilidade a partir de 2009, sobretudo nas Ciências da Saúde, onde começou a aparecer o termo "cuidado espiritual". Na Teologia, estudos sobre cuidado espiritual dentro do contexto da saúde são escassos. Este artigo pretende contribuir com a ampliação desta reflexão. Primeiramente, o cuidado espiritual é abordado a partir da produção científica em língua portuguesa. Em seguida, o modelo interdisciplinar de cuidado espiritual é apresentado como uma abordagem holística de cuidado ao paciente e também são delineadas as consequências da aplicação de um modelo de cuidado espiritual. Discute-se ainda, o papel novo e recém definido dos capelães hospitalares, conselheiros pastorais e cuidadores espirituais. $O$ texto conclui mencionando os principais desafios que acompanham o cuidado espiritual interdisciplinar, especialmente aqueles que dizem respeito ao treinamento dos profissionais do cuidado em saúde.

Palavras-chave: espiritualidade; profissionais da saúde, cuidado espiritual, interdisciplinaridade; capelão hospitalar

Article received on November 15, 2015 and approved on March 15, 2016.

* Doctor of Medicine MD. Post-doctoral research training in religion, spirituality and health at Duke University Medical Center, Durhan/NC. Lecturer for psychosocial medicine at the University of Bern, Switzerland. Diretor of the Research Institute for Spirituality and Health RISH, Switzeland. Country of Origin: Switzerzland. E-mail: rene.hefti@rish.ch

** Psychologist (CRP 08/13082). PhD in Theology (EST,2006), Post-doctoral research in Psicology of Religion (Indiana University South Bend/IN - USA), professor in the Post Graduate Program in Theology and Post Graduate Program in Bioethics at the Pontifical Catholic University of Paraná (PUCPR). Country of Origin: Brazil. E-mail: mary.esperandio@pucpr.br 


\section{Introduction}

Discussions about the integration of spirituality into health care practices gained more space in the international literature in the last two decades (KOENIG, 2001; BALBONI et al., 2010; HEFTI, 2013). In Brazil, the debate became more visible since 2009, mainly in the Health Sciences. There are several earlier studies focusing on the relationship between religion/spirituality and health, but not on the integration of spirituality into health care practices. Thus, as the debate and research on the relationship between spirituality and health grow, the use of the term "spiritual care" began to emerge. Joint Commission, an organization that accredits and certifies health care institutions in the United States, establishes "spiritual care" as an important component to be integrated into patient care. Spiritual care became one of the evaluated items in the accreditation process of institutions. Accordingly, issues related to integration of spirituality into health care practices are now being discussed in Brazilian institutions interested in such certification.

What does the Brazilian scientific literature say about "spiritual care"? Does "spiritual care" belong to any science in particular, as theology or health sciences? Reflecting on these questions, this paper aims to contribute to the ongoing debate. First it presents the results of a literature review on "spiritual care" in the Brazilian (Portuguese) literature. Second it outlines a possible model for interdisciplinary spiritual care described in the International literature and practiced in a Swiss clinic. The paper concludes by pointing out some of the key challenges of integrating religion and spirituality into patient care. 


\section{Concepts of spiritual care in the Brazilian literature}

The debate about a new paradigm in health care viewing the patient from a more holistic perspective emerged in Brazil in the last two decades in the context of discussions about humanizing care. Thus, terms such as "spiritual comfort" (2003 and 2007), "care of spiritual needs" (2005), "spiritual dimension of care" (2007), "spiritual assistance" (2007), "spirituality in the care practice" (2007), "spiritual aspects of care" / "spirituality in care" (2007), and "care in the spiritual dimension" (2009) emerged in literature.

The term "spiritual care", spelled this way, first appeared in the Portuguese literature in a reflective article from Silvia Caldeira (2009). In this article, the author discussed the spiritual dimension of nursing care, introduced the concept of spiritual care, and explored prayer as a practical way of spiritual care in the health context. Caldeira states that

Spiritual care refers to the care of, in and for the spirit. It involves relationship (of), conscious presence (in) and a goal, which is expected to reveal itself in a better health (for), with concern, responsibility and respect for the beliefs of the patient, denying the fact that it is characterized only by doing planned tasks (CALDEIRA, 2009, p. 159).

When defining the meaning of "spiritual intervention", Caldeira points out that "any intervention that supports the connection between the self, others and the sacred, that facilitates the empowerment and results in improved spiritual health can be understood as spiritual care" (CALDEIRA, 2009, p. 159). In this sense, spiritual care is not simply a set of interventions, but an attitude of care. Caldeira refers to the planning of actions by health professionals, focused on the promotion of wellness and meaning of life.

Spiritual care in the health context has also been presented by Pessini and Bertachini as "spiritual care" in the plural, and as "care of the spiritual needs" in a reflective article in 2005, when the authors point to the "new perspectives in 
palliative care" (PESSINI and BERTACHINI, 2005). They acknowledge the "care of the spiritual needs" as the center of philosophy and practice of palliative care.

An older paper, published in 1996, deals with the "spiritual assistance" and spirituality in nursing practice and undergraduate education (BENKO and SILVA,

1996). In an empirical survey with 24 teachers of a large nursing school in Brazil, the researchers concluded that there was not only a lack of clarity on the notions of spirituality, religiosity and spiritual assistance, but also, from the $79.1 \%$ of teachers who declared to address these issues in their disciplines, none of them provided a formal time to do so, leading the authors to believe that the matter was addressed in an unsystematic way and may not equip the student (BENKO and SILVA, 1996, p. 82).

In order to have more clarity about studies in Portuguese on spiritual care, a literature search was conducted in two databases: SciElo - Scientific Electronic Library Online and VHL - Virtual Health Library, using the search terms "spiritual care" + "Brazil" (in Portuguese and in English). 70 articles were found at SciElo and 266 at VHL, totaling 336 articles. The search at VHL was refined in order to select only the articles in Portuguese, resulting in 53 studies. Thus, 123 studies were selected and analyzed. Discarding repetitions and literature reviews not directly related to the theme, 21 articles remained specifically addressing the topic of spiritual care, 11 of VHL and 10 of SciElo. 14 articles were related to nursing, 2 articles to medicine, 2 articles to public health, and 1 article to each of these disciplines: Bioethics, Social Anthropology and Psychology.

Analyzing the content of the 21 articles, they fall into four categories: 1) Theoretical and conceptual studies; 2) Education and training for spiritual care practice; 3) Institutions that integrate spiritual care; 4) Spiritual Care Analysis practiced among Health Professionals. 


\subsection{Theoretical and conceptual studies on Spiritual Care}

Among the four theoretical-conceptual studies (PESSINI \& BERTACHINI, 2005; ELIAS et al., 2007; CALDEIRA, 2009; NASCIMENTO et al. 2010), the first makes a comprehensive presentation of palliative care, placing it in an epistemological and historical perspective. Pessini and Bertachini (2005, p. 506) clarify that spiritual care is at the center of palliative care because such care seeks to "implement a holistic approach to caring for people with life threatening diseases and integrate the physical, social, psychosocial and spiritual dimensions, so that patients and caregivers can face the experience of dying the more mature as possible".

Expanding the field of palliative care, Nascimento et al. (2010) develop a brief reflection on the integration of the spiritual dimension in the context of palliative care in pediatric practice. The authors highlight the need for training nurses for the provision of spiritual care stating that such competence is not unattached to their own spirituality (NASCIMENTO et al. 2010). Elias et al. (2007) discuss a possible method of spiritual intervention called RIME (Relaxation, Mental Images and Spirituality). That program was created by Elias and Giglio for critically ill and terminal patients, based on elements described by patients who had had near-death experiences. The authors applied the method on patients in palliative care, and continuing the study, they developed a training program for health professionals on the use of such intervention (ELIAS et al. 2007), and characterized it as being an alternative and complementary therapy. The study presents the results of the program's application to 11 cancer patients in palliative care. Such intervention program was carried out by 5 health professionals (a doctor, a nurse and three psychologists) who received the training. The results, according to the authors, "suggested that the RIME intervention facilitated the redefinition of spiritual pain of terminal patients, promoting quality of life, dignity and well-being in the dying process" (ELIAS et al., 2007, p. 38-39). 
The study of Caldeira (2009), mentioned at the beginning of this section, in addition to presenting the definition of spiritual care and spiritual intervention, defends the practice of prayer by health professionals, especially by nursing professionals, not only for being a legitimate spiritual intervention technique, present in the International Classification for Nursing Practice (ICNP), but also for being one of the most common coping strategies (CALDEIRA, 2009, p. 160). For Caldeira, one of the reasons for the neglect in providing spiritual care is the recognition of such activity as a specific task of hospital chaplains. Caldeira discusses the risks, challenges and care involved in performing prayer as an intervention, for example, difficulties of nurses in carrying out this activity and the consequent need to ask another professional or chaplain to do it, or the lack of interest of the patient in such intervention, a fact that must be respected.

\subsection{Education and Training for spiritual care practice}

The four qualitative and quantitative studies that address education and training for spiritual care practice point the main barriers to be overcome in addressing this issue. Although nursing students understand the importance of integrating spiritual care, regardless of belief/disbelief of the professional (BENKO \& SILVA, 2005), the majority feels insecure (SOUZA, MAFTUM and MAZZA, 2009) and unprepared (ESPINHA et al. 2013) to do so for not having developed such expertise during the course (MESQUITA et al., 2014; SOUZA, MAFTUM and MAZZA, 2009; ESPINHA et al. 2013; BENKO \& SILVA, 2005). In addition to the problems experienced in the education and training, whether by absence of a specific subject in the curriculum (ESPINHA et al., 2013), or even by the difficulty of the nursing faculty to provide an adequate approach to the subject (BENKO \& SILVA, 2005), the study of Mesquita et al. (2014) points to difficulties related to the own spirituality of the nursing professional as an element that interferes with their ability in the provision of spiritual care. Mesquita and colleagues also observed that the professionals who did not receive specific training on the subject 
indicated greater probability of not providing spiritual care to their patients, and they also presented a positive relation between a greater spiritual welfare of the professionals and the importance the nursing team gave to the provision of spiritual care (MESQUITA et al. 2014).

\subsection{Institutions that integrate spiritual care}

Both studies that exemplify health institutions that integrate spirituality into their care practices refer to institutions kept and managed by Spiritualist groups (LUCCHETTI et al. 2012a; AURELIANO, 2013). These studies classify spiritual care practices offered in these institutions as alternative and complementary therapies. One study (LUCCHETTI et al. 2012a) makes an historical analysis of the contribution of dozens of psychiatric hospitals founded by Spiritualism followers and collects data from 6 spiritualist psychiatric hospitals, aiming to determine the offered spiritual practices, the working structure, health professionals involved, modalities of care, and institutional difficulties in integrating spiritual practices with conventional treatment (LUCCHETTI et al., 2012a, p.128). It is worth mentioning that Spiritualists believe that diseases, especially mental illness, can be caused by the harmful influence of discarnated minds (spirits), and if they are not the cause of the disease, they can be one of the factors associated with worse health outcomes. Spiritualists believe that, because of the symbiotic relationship between the physical body and spirit, diseases that were not cured in past lives are causes of diseases in the incarnated being (LUCCHETTI et al., 2012a, p. 126). Thus, the provision of spiritual care based on the Spiritualist beliefs are offered to patients in treatment, such as the use of magnetized water, study of religious literature, intercessory prayer, disobsession (Spirit release therapy), counseling and spiritual surgery. Similar activities, as well as Reiki, Color Therapy, Bach Flower Remedies and herbal medicines in general are also practices at the Centre for Cancer Patients, as mentioned in Aureliano's study (2013). Some psychiatric hospitals also offer 
Bible studies under the responsibility of Catholic and Protestant religions (LUCCHETTI et al., 2012a, p. 130). Both studies report that such activities are offered to patients with no requirement for participation by them. Aureliano noted that "religious/spiritual elements are highlighted in the understanding of health, disease and forms of care, without necessarily resulting in a membership to a particular group or religious denomination” (AURELIANO, 2013, p. 23).

\subsection{Spiritual Care Analysis practiced among Health Professionals}

The largest number of publications were about the analysis of practices of health professionals in relation to spiritual care, a total of 11 studies. Data shows that in spite of health professionals neglecting the spiritual dimension of patients, patients seek to do this integration from their own internal and external spiritual/religious resources. For example, when investigating the "Pathways of Healing" in populations of the slums of Manguinhos, in Rio de Janeiro, researchers observed that "in popular representations of the disease, the image of disturbance of spiritual balance appears frequently as a cause of illness. The cure depends on recovering this balance" (FERREIRA and ESPÍRITO SANTO, 2012, p. 186). Therefore, according to the authors, the healing systems that emphasize the aspect of religiousness/spirituality are widely accepted in this segment of the population. This perception is reiterated by Souza and Caldas (2009) by analyzing the positioning of Family Health professionals about the relationship between mental health and religiousness in Ilhéus, Bahia. The researchers noted that spirituality appears as a triggering and explanatory factor of mental illness, both in the patient's and health professionals' perception. In addition, professionals recognize that the ties of solidarity and social support received in religious spaces have a positive effect on the daily lives of patients with mental illness in general. However, there are cases where the integration of religiosity in the care of patients with mental illness needs to be better evaluated, in the sense of doing no harm to the 
patient, or protect him from the damage that certain religious beliefs can bring, for example, when the patient decides to leave the allopathic treatment for religious reasons (SOUZA and CALDAS, 2009, p. 465).

Also concerning patients in psychiatric treatment, Lucchetti and colleagues collected data about the interests of patients in receiving spiritual care in spiritualist psychiatric hospitals. The researchers say that most of the 213 evaluated patients, about 85\%, requested spiritual care even when belonging to other religious traditions, including those who did report not belonging to any religion (79.1\%). Patients with a diagnosis of schizophrenia $(\mathrm{p}=.010)$ and lower intrinsic religiosity ( $\mathrm{p}=.002)$ were less likely to request spiritual assistance (LUCCHETTI et al. 2012b).

In the analysis of what "comfort" means for the patient, studies show that the provision of "spiritual comfort" depends fundamentally on a proper analysis of the nursing professionals for the offer of such care (PONTE et al., 2012; FREITAS et al., 2012; MONTEIRO et al., 2014). In this sense, the professional's ability to differentiate between spiritual and religious needs are essential to an adequate care (PENHA \& SILVA, 2012), since the lack of this knowledge leads to an insecure professional when talking about these issues (BRITO et al., 2013).

Regarding the evaluation of care for patients requiring intensive care, researchers say that in these environments care is highly technical and objective; it is aimed at continuous monitoring and medical and nursing care, in order to regain the health of patients (BACKES et al., 2012). There is an overvaluation of the technical care at the expense of emotional, social and spiritual aspects (SILVA \& PEREIRA, 2011). It is possible to infer, according to data of Silva and Pereira (2011), that perhaps exactly due to the excessive preoccupation with technique, stress among professionals can become acute and chronic, since, along with the need for technical performance, there is the concern of nurses with the suffering of the family at the loss (SILVA \& PEREIRA, 2011). 
Finally, a study among hospital chaplains points to their contribution in providing spiritual care to terminally ill patients in seven public hospitals in João Pessoa (FRANCISCO et al., 2015). The study highlights the importance of the chaplain's role and emphasizes the meaning differences among these professionals in understanding what comes to be spirituality, which raises the need for research on this issue, especially in the context of theology.

\section{Spiritual Care in Theology}

The discussion of "spiritual care" in theology has been quite different from that developed in health care. This term is hardly used in Theology in recent decades, with very few exceptions. While discussions on this topic are gaining corpus in the United States and Europe, mainly because of the implications of the integration of spiritual care by the multidisciplinary hospital team, this debate has not been developed in the context of academic reflection in Brazil, until now.

The most recent publications in the Brazilian theology bring a perspective linked to the idea of "pastoral counseling", with specific articles that address the "pastoral care" or even discussing the relationship between spirituality and health. The Theologian and Pastoral Advisor Ronaldo Sathler-Rosa argues that the JudeoChristian tradition, by associating the biblical-theological meaning of salvation and health, establishes relationships between health and spirituality, "although with another grammar and using different foundations" (SATHLER-ROSA, 2014 p.128).

Roese discusses the concept of spiritual care in the light of Tillich's theology and the issues of meaning of life, of Viktor Frankl, in an article about the spiritual and psychotherapeutic care from the feminist perspective (ROESE, 2010).

Research on spiritual care in health care develops a new perception of the hospital chaplain, as well as a theoretical and practical demand of this role, waiting 
for a theoretical construction in Brazil. In the literature review by Gentil and collaborators (2011) about the organization of hospital chaplaincy services, the authors note that the scientific production is recent, located outside Brazil and strongly influenced by the Joint Commission.

Although there are few academic papers on the subject, spiritual assistance to people in Brazilian hospitals is ensured by the Federal Law 9982 of July 14, 2000, and held by many volunteers, religious people, pastors and clergy who are often contacted by hospitals to provide spiritual care to patients who request for it or to whom it is offered by nurses who are sensitive to patient needs.

The current debate on spiritual care in hospital settings point out that new skills and competences are needed to perform chaplaincy services and practice. It demands the provision of a spiritual care based on inter-religious and intercultural perspectives by the hospital chaplain, or people involved in this task (whether religious or lay people and volunteers), a practice intentionally focused on the spiritual needs of the patient, regardless of the chaplain's faith tradition. In this sense, hospital chaplains need to have new capabilities, attitudes and knowledge in order to better perceive and meet the spiritual needs of the suffering person.

The reflection developed here helps us to understand the interdisciplinary character of spiritual care. No scientific field will meet the challenges alone. Theoretical and practical proposals, as well as empirical studies in an interdisciplinary perspective can significantly contribute in promoting a more humane care.

\section{The Interdisciplinary Spiritual Care Model}

The challenging question is how to realize a holistic or whole-personapproach in the clinical setting. Therefore a new model has been developed - we call it "Interdisciplinary Spiritual Care Model". The aim of this chapter is to outline this new model in more detail and to highlight its relevance for health care. 
A cornerstone on the way to a more holistic approach in medicine was the biopsychosocial model as described and published by George Engel (1977). This model placed the patient within a biopsychosocial framework integrating biological, psychological and social factors contributing to the etiology and the course of disease. However, Engel's model still neglects an important aspect: the existential dimension of the patient (DAALEMAN \& NEASE, 1994; KING \& BUSHWICK, 1994). Therefore the biopsychosocial model had to be further developed.

\subsection{Theoretical Foundations}

The spiritual care model is rooted in a holistic view of the patient as well as disease, integrating biological, psychological, social and spiritual aspects. In a holistic understanding disease is not only a biological dysregulations of genes. Of equal importance are epigenetic factors related to the psychosocial and spiritual domain.

Sulmasy, author of the frequently cited article on the "biopsychosocialspiritual model in end of life care" (2002) based his approach on what he calls philosophical anthropology proposing that humans are intrinsically spiritual by being fundamentally oriented towards relationship. Ancient people understood sickness as a disturbance in relationships. The task of the shaman was to heal by restoring the relationship between the sick person and the cosmos. Thus, healing was a religious act, consisting in the restoration of right relationships (SULMASY, 2002, p. 25). Contemporary scientific healing, according to Sulmasy, also consists of the restoration of right relationships, but has limited this to the restoration of homeostatic processes in the body. Yet illness disturbs more than processes in the human organism. It disrupts families and workplaces, shatters preexisting patterns of coping and raises questions about one's relationship with the Transcendent (SULMASY, 2002, p. 26). Sulmasy's reflection on the religious/spiritual needs of 
the patient at the end of life leads him to propose a "biopsychosocial-spiritual model of care for the dying person”. However, as several studies have shown, spiritual needs emerge not only at the end of life, but anytime when a person feels life is threatening, particularly in times of illness and suffering.

The holistic model proposd by Hefti (2013) is based on existential philosophy. Victor Frankl's view of human being introduces the noetic or spiritual dimension that is clearly distinct from the psychic or somatic and considered to be the genuinely human (FRANKL, 1959). An expression of the noetic dimension is what Frankl called the "will of meaning", the basic motivational structure of the individual as a human being (FRANKL, 1984). Meaning in Frankl's understanding is self-transcending and therefore spiritual. It is oriented towards the world and its objective values. The concept of "person", another central concept in Frankl's anthropology, integrates the somatic, the psychic and the noetic thus building the proposed anthropological unity.

Integrating Frankl's anthropology into George L. Engels biopsychosocial model constitutes what Hefti (2013) called the "extended biopsychosocial model" (figure 1) or in other terms the "bio-psycho-socio-spiritual model". Religiosity and spirituality are understood as a distinct and independent anthropological dimension interacting with the other dimensions of the biopsychosocial model. Religion can be a causing, mediating or moderating factor on any biological, psychological or social outcome. As an example religiosity moderates (buffers) the physiological stress reaction (MASTERS et al, 2004; HEFTI, 2009), a possible pathway explaining the religion-health connection. 


\section{Figure 1. The extended biopsychosocial model integrates religion and} spirituality as a fourth dimension into the George L. Engels biopsychosocial model.

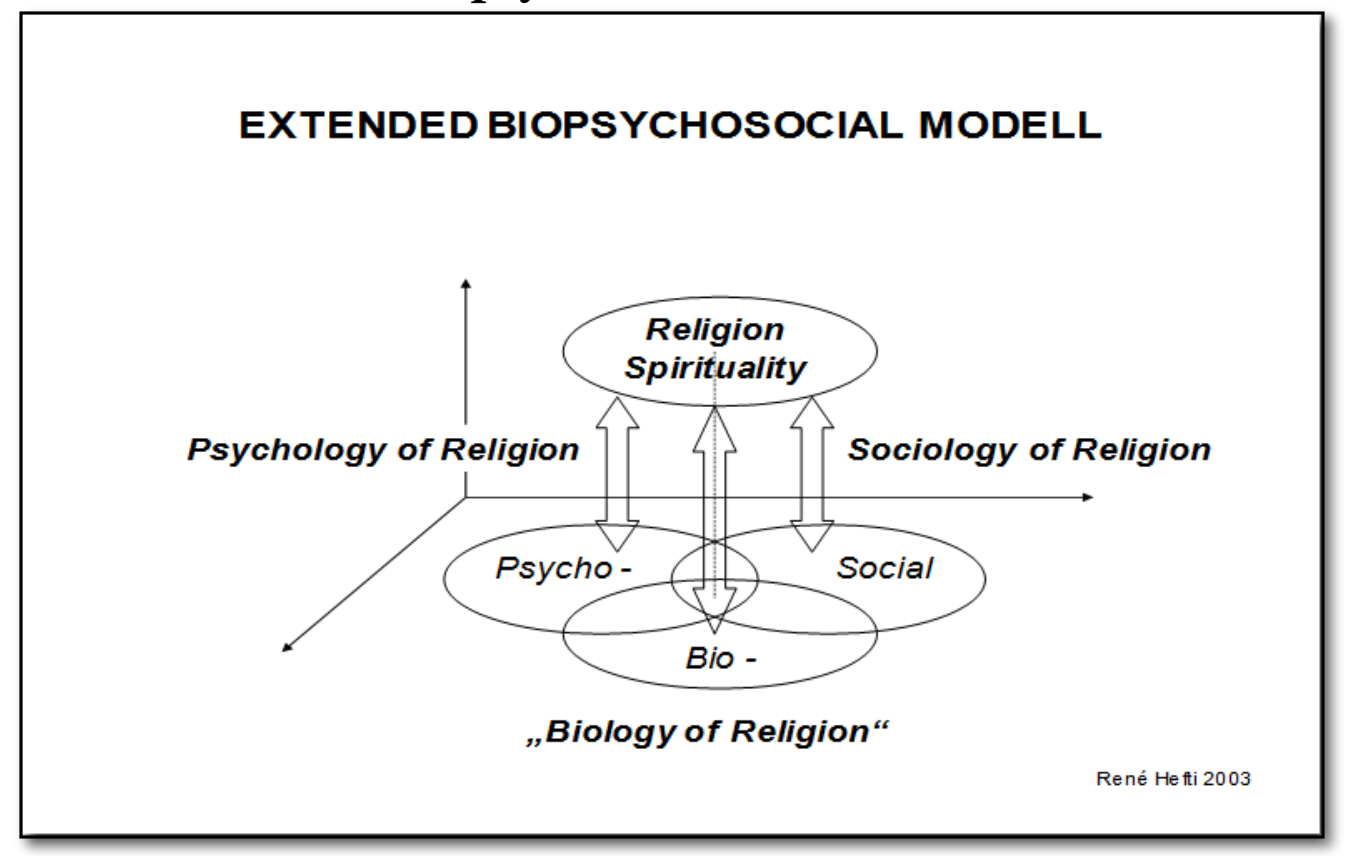

Source: HEFTI, Unser Therapiekonzept, Infomagazin 2003

The extended biopsychosocial model also points out that patients - beside biological, psychological and social needs - have spiritual needs as well (such as the need for hope; for meaning and purpose; the need to feel connected with him/herself, with others and the transcendent; the need to feel loved). These spiritual needs become even more prominent during times of sickness and suffering, as several studies showed (KOENIG, 2012). Patients also have religious and spiritual resources often enabling them to better cope with disease and life threatening situations. Supporting religious and spiritual coping is an important aspect in total patient care. Of equal importance is the assessment of spiritual struggles and spiritual distress (MONOD et al., 2010), often interfering with the recovery process. 


\subsection{The Interdisciplinary Health Care Team and the Role of the Chaplain as a Professional Caregiver}

Patient Care with a few exceptions is always characterized by an interdisciplinary setting involving doctors (from different specialties), nurses, physiotherapists, psychologists, social workers, other professionals and chaplains (see figure 2). The interdisciplinary collaboration is highly important for the overall success of the treatment. The interplay between the disciplines is complex and must be managed the best possible way reducing misunderstandings, role conflicts, and overlaps. Therefore the standard interdisciplinary team model defines spheres of responsibility for each health profession involved. The physician usually is the team leader and carries the final responsibility for the patient and the treatment as a whole. Partnership between the disciplines and patient centeredness are crucial, putting the patient in the focus of all medical and caring activities.

\section{Figure 2. The Interdisciplinary Health Care Team (IHCT)}

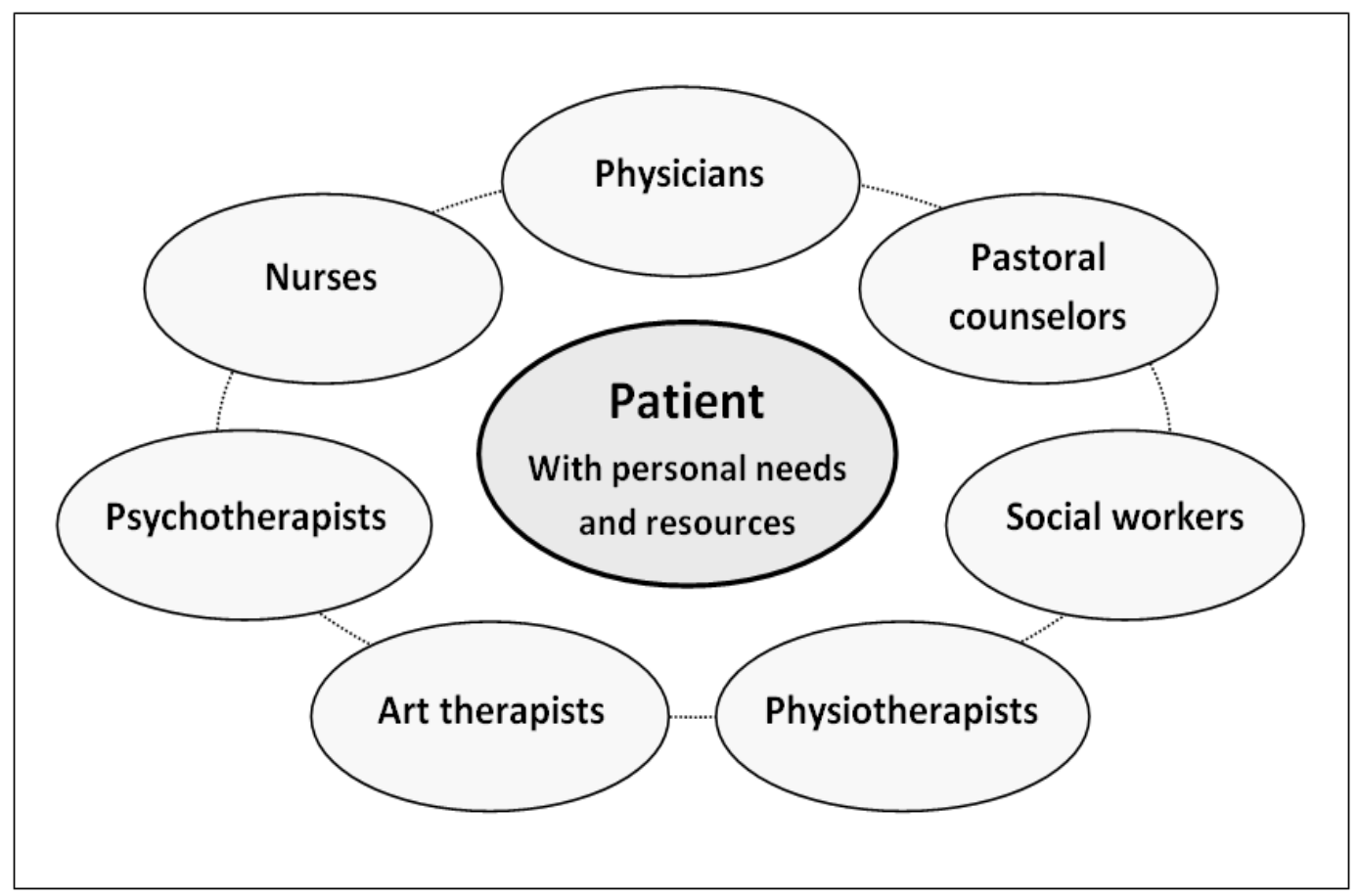

Source: HEFTI, Integrating spirituality, Cambridge 2009 
The role of hospital chaplains (spiritual caregivers) depends on the cultural context and their form of employment. Different countries have different ways of understanding the role and the importance of hospital chaplains. For instance, in the United States, chaplains are employed by the hospitals. The relevance of chaplaincy is well recognized, particularly, by the Joint Commission International ${ }^{1}$ (formerly known as Joint Commission on the Accreditation of Healthcare Organization - JCAHO), as well as the Canadian accreditation agency. Such agencies state that "patients have a fundamental right to considerate care that safeguards their personal dignity and respects their cultural, psychosocial, and spiritual values" (JCAHO, 1998). Chaplains in the USA are well trained, and studies on their work have suggested positive effects of their visits on hospitalized patients (ILER, OBENSHAIN, CAMAC, 2001). After analyzing three published investigations (ILER, OBENSHAIN, CAMAC, 2001; FLANNELLY et al. 2005; BAY et al., 2008) on chaplaincy services, Cummings \& Pargament concluded that "chaplaincy services may promote beneficial (rather than harmful) forms of religious coping, physical recovery, and emotional well-being, all of which should be important to health professionals (CUMMINGS \& PARGAMENT, 2010, p. 44).

On the European Continent, the European Network of Health Care Chaplaincy - ENHCC 2 is an organization that links health care chaplaincy across Europe. As a network, they have built a collective statement which became "a point of reference and a guide for all faiths and denominations in shaping spiritual care offered in the area of health care". The ENHCC reports that "chaplaincy services are organized in different ways in different European countries, and it is shaped by religious faith group administration; health care institutions; state health care regulation and policies; chaplaincy associations". The organization also informs that

\footnotetext{
${ }^{1}$ The Joint Commission International is a Non Profit Organization settled in the United States that certifies more than 2,500 healthcare organizations according to the quality of services provided. Proper care of the spiritual needs of the patient in treatment is one of the required services that an institution must provide in order to receive such a certification.

${ }^{2}$ Information about this organization can be found at European Network of Health Care Chaplaincy.
} 
chaplaincy services are delivered by clergy and lay persons who have been professionally trained in the area of pastoral care. They are authorized by their faith community and recognized by the health care system. Chaplaincy services work as part of the multi-disciplinary team (EUROPEAN NETWORK OF HEALTH CARE CHAPLAINCY, 2015).

If chaplains are employed by the hospital or the institution, they are usually part of an interdisciplinary team. If they are employed by the church or another religious institution and have a full-time engagement in the hospital it is basically the same. If they are employed by the church or another religious institution and have a full time engagement in the community they are usually not part of the team. They have to coordinate their activities with the health care team on their own initiative.

\subsection{The Interdisciplinary Spiritual Care Model}

The key question regarding a spiritual care model is the following: Who takes care of the spiritual needs and struggles of the patient and who supports their spiritual resources? In the standard interdisciplinary team model the answer is more or less clear: the pastoral counselor or spiritual caregiver is responsible for the "spiritual wellbeing" and the "spiritual support" of the patient. So he/she has to be informed by the health care team or he/she has to visit all patients systematically, which usually is not the case and mostly is not possible.

In a "Interdisciplinary Spiritual Care Model" (see figure 3) the team shares responsibility on spiritual matters. That means that every team member is able to assess spiritual needs or struggles of a patient, document them in the patient record and communicate them in the team meetings (or directly with the pastoral counselor). Typically doctors, nurses and psychotherapists take a short spiritual history. Physicians, as the leader and main responsible of the treatment team, have to assure that the spiritual needs of the patients are met and spiritual struggles are assessed. Both of them can interfere significantly with the treatment regime. 


\section{Figure 3. The Interdisciplinary Spiritual Care Model (ISCM)}

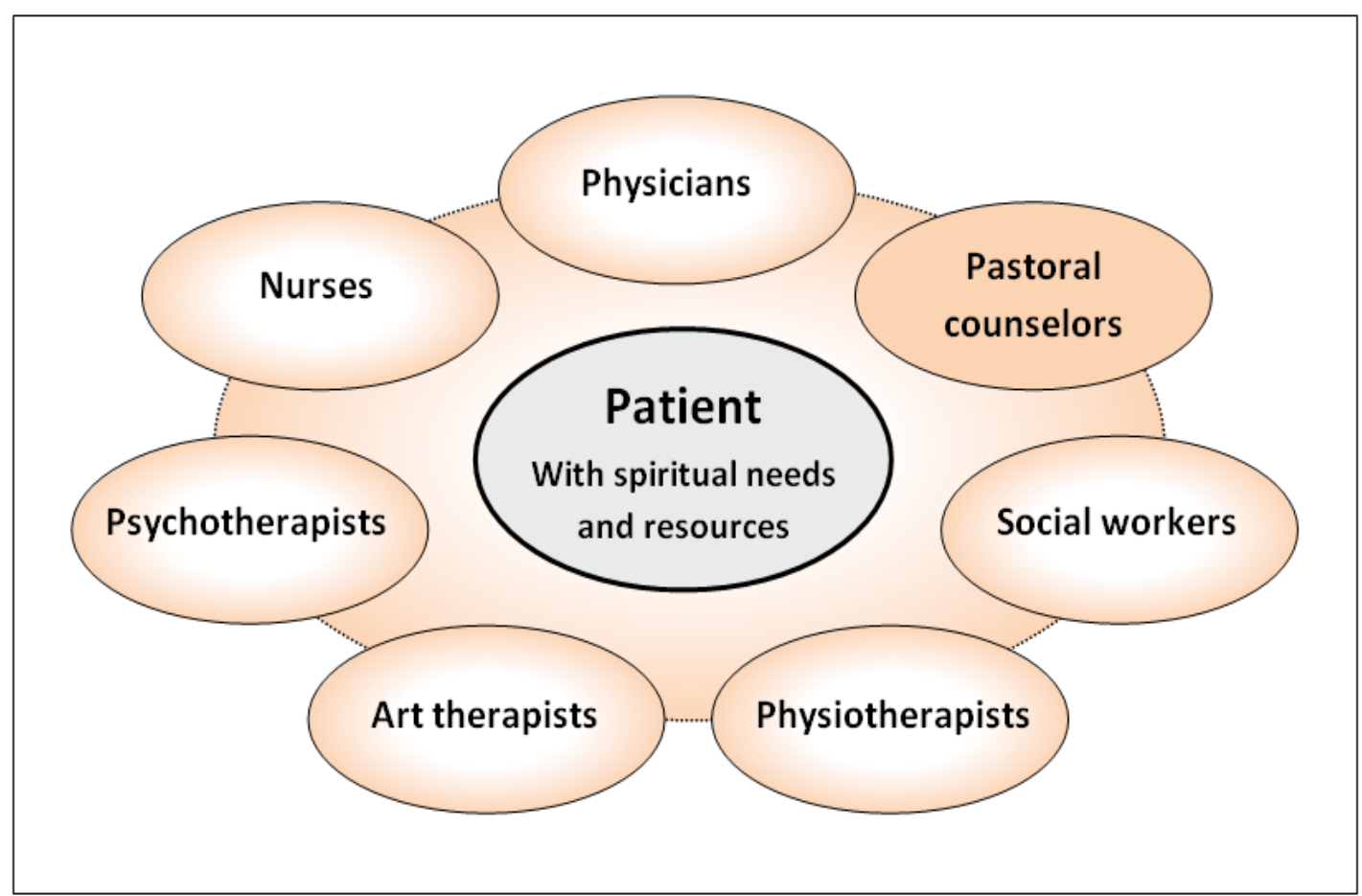

Source: HEFTI, International Seminar, Curitiba/Brazil 2015

To establish an Interdisciplinary Spiritual Care Model team member's need additional training on how to take a spiritual history, assess spiritual needs, identify spiritual struggles and support spiritual ressources. The role of the pastoral counselor becomes two-sided: on one hand he is the spiritual care expert administrating professional pastoral and spiritual care; on the other hand he/she has an important role in teaching and supporting the interdisciplinary team. 


\subsection{Do Patients Want Clinicians to Address Their Spiritual Concerns?}

All of our theorizing would be useless if patients were uninterested in medical attention to their spiritual needs and concerns. But clinical experience goes along with what a number of studies showed. The majority of patients want their physicians to address spiritual matters (DAALEMAN \& NEASE, 1994; EHMAN et al., 1999; KING \& BUSHWICK, 1994; LUCCHETTI et al. 2012b). A Brazilian study shows that $53 \%$ of health professionals believe that patients would like to discuss spiritual issues during the treatment course, however, only $18,1 \%$ of professionals report they do this regularly (ESPERANDIO, 2014, p. 822). Even $45 \%$ of nonreligious patients thought that physicians should inquire politely about patients' spiritual needs (MOADEL et al., 1999). This is particularly true if they are at the end of life. These results are corroborated by surveys regarding patients' desire for nursing attention to their spiritual concerns (REED, 1991). Nonetheless, if patients reply that they do not have spiritual or religious concerns or do not wish them to be addressed in the context of the clinical relationship, the clinician must always respect the patient's refusal (SULMASY, 2001).

Physicians have generally been reluctant to address patients' spiritual needs and concerns in practice (ELLIS, VINSON, \& EWIGMAN, 1999). In one study, oncologists rated spiritual distress low compared with 17 other clinical concerns they felt to be responsible for addressing (KRISTELLER, ZUMBRUN, \& SCHILLING, 1999). Physicians make referrals to chaplains or otherwise address these patients' spiritual issues less than $1 \%$ of the time (SULMASY et al., 1992). 


\section{Practicing a Spiritual Care Model}

According to German researchers on this topic (PAAL, HELO \& FRICK, 2015), spiritual care does not "work" like most other interventions in health care that provide relief from suffering or eliminate pathologies. Much more than attaining goals, spiritual care means accompanying the patient's journey through presence, words, and humble acts of caring. The pivotal point of spiritual care is taking the patient's spiritual history, in order to put together a "diagnosis" and a strategy for therapy within the multi-professional team. It is, however, not the history of an illness but a personal biography encompassing resources, needs, belongings, perhaps crisis and distress.

\subsection{Taking a Spiritual History}

Taking a spiritual history enables the health care professional to understand the role that religion or spirituality play in patient's coping with disease and helps to identify patient's spiritual needs. Furthermore taking a spiritual history is a powerful act in itself and opens up a further dimension in the doctor-patientrelationship, sending the message to the patient that this aspect of his or her identity is recognized and respected. It helps to gather important information that is useful for understanding the motivation behind patient's behaviors related to health. It also provides information about patients' support systems and resources within the community.

Several instruments have been developed to take a spiritual history. It is not essential what instrument the health professional uses but it is important to collect certain information and to do so in a sensitive manner. The questions should be brief and take only a few minutes to administer. They must be easy to remember and effective in gathering the type of information sought. The purpose is to 
understand patient's beliefs and what role they play in health and illness, without judgment or attempt to modify those beliefs or lack of belief.

Christina Puchalski, associate professor of medicine at George Washington University Medical Center and director of the George Washington Institute for Spirituality and Health, has developed the following five questions that are easily remembered using the income tax mnemonic FICA (PUCHALSKI \& ROMER, 2000)

- F-faith-What is your faith tradition?

- I-importance-How important is your faith to you?

- C-church-What is your church or community of faith?

- A-apply-How do your religious and spiritual beliefs apply to your health?

- A-address-How might we address your spiritual needs?

Furthermore it is very important to assess "spiritual distress". Monod et al. (2010) developed the Spiritual Distress Assessment Tool (SDAT) to evaluate spiritual distress in hospitalized elderly patients. The hypothesis was made that spiritual distress arises from unmet spiritual needs. The greater the degree to which a spiritual need remains unmet, the greater the level of spiritual distress experienced by the patient. Spirituality was defined as a multidimensional concept that includes four main dimensions: Meaning, Transcendence, Values and Psychosocial Identity. Related spiritual needs were systematically defined for each dimension. A structured assessment procedure to identify these spiritual needs and score the degree to which they remain unmet was developed.

Before beginning the spiritual history, health professionals should explain to the patient why these questions are being asked. The health professional (e.g. doctor, psychotherapist) can communicate to the patient that he or she has a few questions about spiritual beliefs and that this has nothing to do with the patient's condition but rather reflects a desire to be more sensitive to spiritual needs. Delegating these questions to the chaplain is not sufficient, since 80 percent of 
patients will not see a chaplain. Asking these questions will provide firsthand knowledge of the answers so that the health professional who is responsible for the patient can assure that spiritual needs are met and that medical decisions are made in light of them.

If the patient indicates at the beginning of the spiritual history that he or she has no interest in religion or spirituality and that these factors play no role in coping with illness, the spiritual history should take a different track. Rather than focusing on spirituality or religion, the interviewer might ask about how the patient is coping with his situation, what gives life meaning and purpose in the setting of the current illness, what cultural beliefs are held that may influence the treatment of the illness, and what social resources are available to provide support at home. In this way, vital information is collected while not offending the patient or making the patient feel uncomfortable.

The spiritual history (including spiritual needs) should be documented in the medical record avoiding the problem of repeating the spiritual history by another health professional, and thereby overwhelming or irritating the patient. Any health professional can simply turn to the medical record to see if the spiritual history has been taken and what was learned.

\subsection{Supporting Religious Coping and Spiritual Beliefs}

Several surveys showed a high prevalence of religious coping among patients with physical as well as mental disease (KOENIG, 1998; TEPPER et al., 2001). Tepper et al. (2001) investigated 406 patients at one of thirteen Los Angeles County mental health facilities. More than 80 percent of the participants used religious beliefs or activities to cope with daily difficulties or frustrations. A majority of participants devoted as much as half of their total coping time to religious practices, with prayer being the most frequent activity. Studies show that 
prayer is the most employed strategy with difficult situations such as the process of health-illness (ESPERANDIO \& LADD, 2015; ESPERANDIO, 2014).

This is also true for Europe. The findings of Tepper et al. have been replicated by Mohr et al. (2006) in Geneva, Switzerland. Semi-structured interviews focused on religious coping were conducted with a sample of 115 outpatients with psychotic illness at one of Geneva's four psychiatric outpatient facilities. For a majority of patients, religion instilled hope, purpose, and meaning in their lives (71\%), whereas for some, it induced spiritual despair (14\%). Patients also reported that religion lessened (54\%) psychotic and general symptoms and increased social integration (28\%). It reduced the risk of suicide attempts (33\%) and substance use (14\%). The results highlight the clinical significance of religious coping for patients with schizophrenia.

Even if the patient's beliefs are different from those of the health professional believes, the purpose is to enter into the worldview of the patient in order to understand why the patient believes as he or she does. If religious and spiritual beliefs are not interfering with medical care and are not obviously pathological or harmful, then supporting these beliefs and practices should be considered. In the light of a growing number of studies it is appropriate or even "good practice" to do so. The goal is not to make patients more religious or spiritual, but rather to reinforce effective coping that may affect the outcome of the illness. The intention of the health professional is always to maximize health outcome. Keeping the support patient centered and ensuring that the goal of the support is health related are both crucial. The health professional is nurturing and supporting the patient's own faith.

If a health professional is uncomfortable in doing so, it is his or her responsibility to refer the patient to a Spiritual Care specialist, e.g. a professional chaplain. Professional chaplains are the true experts in the health care setting. Certified chaplains have gone through extensive training to meet the spiritual 
needs of medical or psychiatric patients. That training typically involves one or more years of clinical pastoral education in a hospital setting. If chaplains are not available, then pastoral counselors or trained clergy from the patient's religious denomination should be consulted. Some patients, however, may refuse to see a chaplain. Having a long-term relationship with a health professional could make the patient feel more comfortable discussing religious worries or doubts with that person. In such situations, the health professional should take a few minutes to clarify concerns by listening to the patient in a caring and supportive manner. Sometimes, relatively simple interventions by the physician or another health professional are enough to resolve the issue. Listening with respect and concern may be all that is needed.

These findings reflect the experiences made in a Swiss clinic for psychosomatic medicine, psychiatry and psychotherapy in Langenthal, Switzerland. For a majority of patients, religious or spiritual coping is an essential part of their coping behavior. Religion provides patients with a framework to cope with disease-related struggles. To illustrate this, a passage from an open, unstructured interview with a depressed 65-year-old female patient, who participated in a qualitative study, demonstrates how she controls her depressive feelings:

When I wake up early in the morning and can't sleep anymore then I go outside, speak with God, thanking him for being in control and for not letting me go down. In past times I always began to ask why, why did I marry this man, why did God let this happen? But this made things worse. Today I stop this kind of thinking (SCHMIDT, 2008, p. 62). 


\subsection{The Interdisciplinary Spiritual Care Model of a Swiss Clinic}

As an example on how spiritual care can be implemented in hospital setting the concept of the SGM Clinic Langenthal, Switzerland, will be outlined.

\section{Picture 1. SGM Clinic Langenthal in Switzerland}

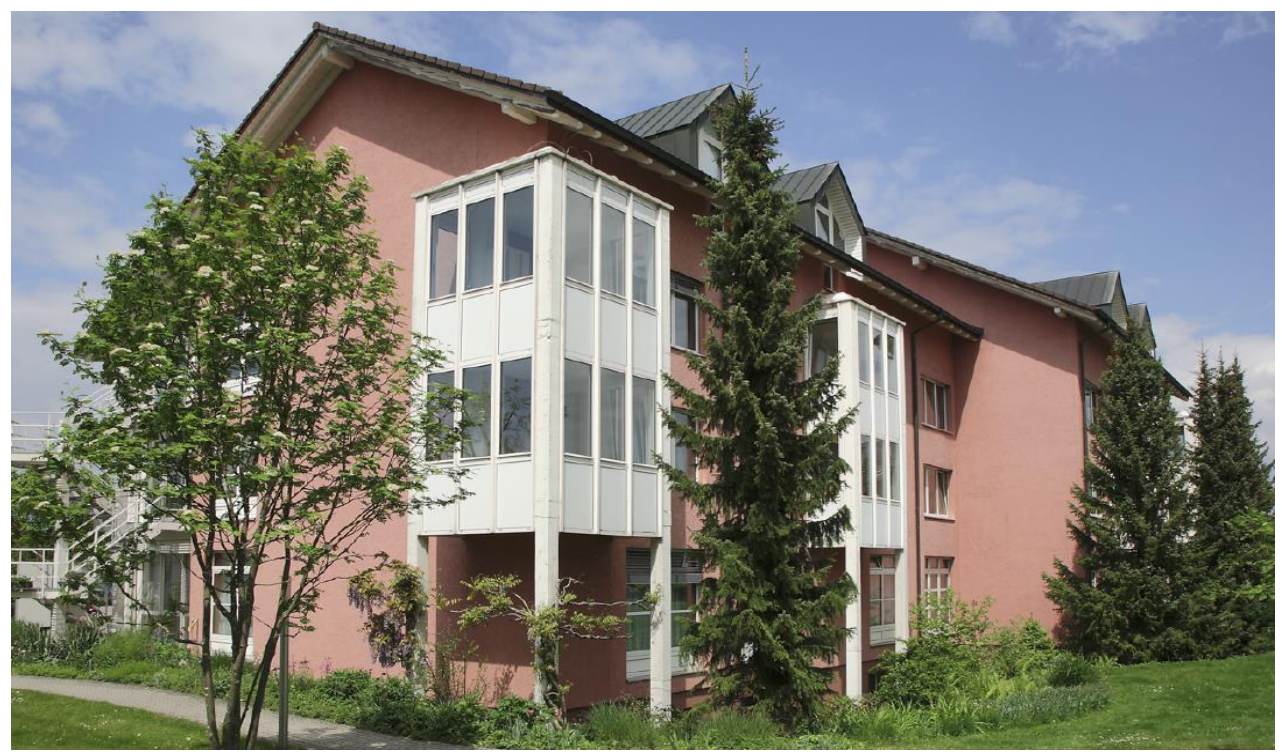

Source: SGM Clinic Langenthal, Archive

The SGM Clinic Langenthal is specialized for psychosomatic medicine, psychiatry and psychotherapy and has an inpatient and an outpatient department. A basic assumption behind the therapeutic concept of the clinic is that there is always an existential and therefore a spiritual dimension in mental as well as in physical disease . Therefore a spiritual history is taken in every patient exploring whether and how religion or spirituality determine patient's understanding of illness and healing. If a patient has a religious or spiritual background, spiritual treatment goals will be defined (e.g.): 
- Regaining hope and meaning despite illness and suffering

- Strengthen the relationship with God to better cope with daily hassles

- How to persevere in difficult psychosocial circumstances

- Resolving anger, frustration or disappointment towards the transcendent

- Understanding why God allows bad things to happen in patients' lives

- Working towards forgiveness in broken relationships

- Being more aware of God's presence and guidance in daily life

Spiritual treatment goals are discussed in the interdisciplinary team, of which the pastoral counselor is an active member. They have to be in line (not in conflict) with the other treatment goals. Religion and spirituality can be (mis)used as a way to escape from difficult circumstances, what is not endorsed. For many years the clinic has offered psycho-educational group meetings focusing on the integration of therapeutic and spiritual aspects, emphasizing the benefit and importance of religious and spiritual coping (TEPPER et al., 2001; PARGAMENT, 1997; PHILIPS, 2002).

Furthermore, the clinic offers a spiritual issues discussion group led by the pastoral counselor (KEHOE, 1999; WONG-McDONALD, 2007). Participants can introduce spiritual topics, questions or problems related to their illness or individual situation. The topics are discussed in the group and the pastoral counselor shares insights from his spiritual background. Participants learn how to use their own spiritual resources, how to cope with spiritual distress and struggles related to their illness.

Integrating spiritual issues in professional psychotherapy (PROPST et al., 1992) represents another form of spiritual care and support. A patient in a submanic/psychotic state felt energized by God's overwhelming presence in his mind and body. The therapist discussed this "spiritual perception" with the patient in the psychotherapeutic sessions evaluating other possible explanations. Other topics coming up in psychotherapy are feelings of guilt, shame, being rejected or abandoned by the divine, working towards forgiveness and reconciliation. 
The clinic also provides conventional pastoral care and counseling to meet the specific religious and spiritual needs of patients. This includes rituals and sacraments, e.g., anointing with oil or taking the Lord's Supper. The pastoral counselor is a full member of the interdisciplinary spiritual care team, enabling the other health care professionals to give spiritual support to patients (see figure 3).

There is also a patient library providing a wide range of religious and spiritual literature “Canvas of Love - Reflections on a Rembrandt” by Henri J. M. Nouwen, telling and commenting the story of the two sons and the father, known as the parable of the prodigal son (Luke 15, 11-32) is one of the favorite books.

\section{Summary and Conclusions}

In the international literature, "interdisciplinary spiritual care" is a well established topic. Spiritual care models are discussed (SULMASY, 2002; PUCHALSKY et al., 2006; HEFTI, 2013) and applied to different clinical settings as palliative care, serious chronic illness, psychosomatic medicine and psychiatry. Puchalsky states: "Spiritual care is interdisciplinary care" (PUCHALSKY et al., 2006, p. 398). In the Brazilian context spiritual care became a topic since 2009 mainly in the health sciences. Preliminary models have been described and clinical applications tested, mainly in religious institutions (LUCCHETTI, 2012a).

A main challenge in interdisciplinary spiritual care is to provide an effective, team oriented training. Every member of the interdisciplinary spiritual care team has to adopt basic skills and competencies in spiritual care. This includes a genuine understanding of the spiritual care model, interdisciplinary collaboration with the pastoral counselor or spiritual caregiver, assessing spiritual beliefs and screening for spiritual needs, resources and struggles. Furthermore it requires knowledge about different faith traditions, spiritual interventions, professional borders, and finally a continuous reflection on one's own spirituality. 
A consensus conference published in the Journal of Palliative Medicine (PUCHALSKY et al., 2009) offers detailed recommendations and guidelines. Another useful source is Harold G. Koenig's book Spirituality in Patient Care: Why, How, When and What. It outlines the integration of spiritual care in the different health professions based on recent research (KOENIG, 2013). A comprehensive overview on the integration of religion and spirituality into mental health care, psychiatry and psychotherapy was written by Hefti (2011) and can be downloaded from the freely accessible online journal "Religions".

The Portuguese literature review points out the necessity for research and reflection on the role of hospital chaplains in the context of spiritual care. Interdisciplinary spiritual care requires new skills and competencies as mentioned earlier in this article. The role of the hospital chaplain becomes two-sided: on one hand he/she is the spiritual care expert administrating professional pastoral and spiritual care; on the other hand he/she has an important role in teaching and supporting the multiprofessional team.

Further studies on interdisciplinary spiritual care are needed to better shape the professional training required. Key topics like religious coping and spiritual struggles have to be identified and integrated. Active participation of theology, psychology of religion and bioethics could contribute significantly to the further development of spiritual care in Brazil and elsewhere. 


\section{REFERENCES}

AURELIANO, W. A. Terapias espirituais e complementares no tratamento do câncer: a experiência de pacientes oncológicos em Florianópolis (SC). Cad. saúde colet., Rio de Janeiro, vol.21, n.1, p. 18-24, 2013.

BALBONI, T.A. et al. Provision of Spiritual Care to Patients with Advanced Cancer: Associations with Medical Care and Quality of Life Near Death. Journal of Clinical Oncology, New York, vol. 28, n. 3, p. 445-452, 2010.

BAY, P.S. et al. The effect of pastoral care services on anxiety, depression, hope, religious coping, and religious problem solving styles: A randomized controlled study. J. Relig. Health, New York, v. 47, p. 57-69, 2008.

BACKES, M. T. S. et al. O cuidado intensivo oferecido ao paciente no ambiente de Unidade de Terapia Intensiva. Esc. Anna Nery, Rio de Janeiro, v. 16, n. 4, p.689696, 2012.

BENKO, M.A. \& SILVA, M.J.P. Pensando a espiritualidade no ensino de graduação / Thinking about spirituality within nursing undergraduate program / Pensando en la espiritualidad en la enseñanza de pre-grado, Revista Latino-Americana de Enfermagem. Ribeirão Preto, v. 4, n. 1, p. 71-85, 1996.

BRITO, F. M. et al. Espiritualidade na iminência da morte: estratégia adotada para humanizar o cuidar em enfermagem / Spirituality in iminent death: strategy utilized to humanize care in nursing. Rev. enferm. UERJ, Rio de Janeiro, v. 21, n. 4, p. 483-9, 2013.

CALDEIRA, S. Cuidado Espiritual - Rezar como intervenção de enfermagem / Spiritual Care - Prayer as a nursing intervention / Cuidado Espiritual - Rezar como intervención de enfermaria, CuidArte Enfermagem. FIPA, Catanduva, v. 3 , n. 2, p. 157-164, 2009.

CANADIAN COUNCIL ON HEALTH SERVICES ACCREDITATION. Achieving Improved Measurement (AIM) Program. Ottawa, Canada, KlG 5L1. Sections $13.3 \& 14.9 .1999$.

CUMMINGS J.P., PARGAMENT K.I.. "Medicine for the Spirit: Religious Coping in Individuals with Medical Conditions”. Religions, Basel, v. 1, n. 1, p. 28-53, 2010. 
DAALEMAN, T. P.; NEASE, D. E. Patient attitudes regarding physician inquiry into spiritual and religious issues. Journal of Family Practice, New York, v. 39, p. 564-568, 1994.

EHMAN, J.W. et al. Do patients want physicians to inquire about their spiritual or religious beliefs if they become gravely ill? Archives of Internal Medicine, Chicago, v. 159, p. 1803-1806, 1999.

ELIAS, A. C. A. et al. Programa de treinamento sobre a intervenção terapêutica "relaxamento, imagens mentais e espiritualidade" (RIME) para re-significar a dor espiritual de pacientes terminais. Rev. psiquiatr. clín., São Paulo, v. 34, supl. 1, p. 60-72, 2007.

ELLIS, M.R., VINSON, D.C. ; EWIGMAN, B.. Addressing spiritual concerns of patients: Family physicians' attitudes and practices. Journal of Family Practice, New York, v. 48, p. 105-109, 1999.

ENGEL, G.L. The need for a new medical model: a challenge for biomedicine. Science, New York, v. 196, n. 4286, p. 129-36, 1977.

ESPINHA, D.C.M. et al. Opinião dos estudantes de enfermagem sobre saúde, espiritualidade e religiosidade / Opiniones de los estudiantes de enfermería sobre la salud, la espiritualidad y la religiosidad, Revista Gaúcha Enfermagem, Porto Alegre, v. 34, n. 4, 2013.

ESPERANDIO, M.R.G. Teologia e a pesquisa sobre espiritualidade e saúde: um estudo piloto entre profissionais da saúde e pastoralistas. Horizonte, Belo Horizonte, v. 12, n. 35, p. 805-832, jul./set. 2014.

ESPERANDIO, M.R.G.; LADD, K.L. I Heard the Voice, I Felt the Presence. Prayer, Health and Implications for Clinical Practice. Religions, Basel, vol. 6, n. 2, p. 670-685, 2015 .

ESPERANDIO, M.R.G. Rev. Prayer and Health. A Portuguese Literature Review. Pistis Prax., Teol. Pastor., Curitiba, v. 6, n. 1, p. 51-66, jan./abr. 2014

EUROPEAN NETWORK OF HEALTH CARE CHAPLAINCY. Standards for Health Care Chaplaincy in Europe. Available at: <http://enhcc.eu/turku_standards.htm > Acessed: 10 oct 2015 .

FERREIRA, J.; ESPÍRITO SANTO, W. Os percursos da cura: abordagem antropológica sobre os itinerários terapêuticos dos moradores do complexo de favelas de Manguinhos, Rio de Janeiro, Physis - Revista de Saúde Coletiva. Rio de Janeiro, v. 22, n. 1, p. 179-198, 2012. 
FRANCISCO, D. P. et al. Contributions of the chaplaincy service to the care of terminal patients. Texto contexto - enferm., Porto, v.24, n.1, p. 212-219, 2015.

FRANKL, V.E.. The spiritual dimension in existential analysis and logotherapy. Journal of Individual Psychology, Austin, v. 15, p. 159-164, 1959.

FRANKL, V.E.. Men's search for meaning. Washington Square Press, 1984.

FLANNELLY, K.J. et al. Department directors' perceptions of the roles and functions of hospital chaplains: A national survey. Hospital Topics, Washington, v. 83 , p. $19-27,2005$.

FREITAS, K. S.; MENEZES, I. G.; MUSSI, F. C. Comfort from the perspective of families of people hospitalized in the Intensive Care Unit. Texto contexto enferm., Porto, v. 21, n. 4, p. 896-904, 2012.

GENTIL, R. C.; GUIA, B. P.; SANNA, M. C.. Organization of Hospital Chaplaincy Services: a bibliometric study. Escola Anna Nery (impr.), Rio de Janeiro, v. 15 n. 1, p. 162-170, jan-mar. 2011.

HEFTI, R. Integrating Spirituality into Therapy. In: HUGUELET, P.; KOENIG, H. (ed.). Religion and Spirituality in Psychiatry. New York: Cambridge University Press, p. 244-267, 2009.

HEFTI, R. Integrating Religion and Spirituality into Mental Health Care, Psychiatry and Psychotherapy. Religions, Basel, v. 2, n. 4, p. 611-627, 2011.

HEFTI, R. The Extended Biopsychosocial Model: A whole-person-approach to psychosomatic medicine and psychiatry. Psyche \& Geloof, Zoetermeer, v. 24, p. 119-29, 2013.

ILER, W.L.; OBENSHAIN, D.; CAMAC, M. The impact of daily visits from chaplains on patients with chronic obstructive pulmonary disease. Chaplaincy Today, Schaumburg, v. 17, n.1, p. 5-11, 2001.

JOINT COMMISSION ON THE ACCREDITATION OF HEALTHCARE ORGANIZATIONS (JCAHO). CAMH Refreshed Core, January, RI1, 1998.

KEHOE, N.C.. A therapy group an spirituality issues for patients with chronic mental illness. Psychiatric Services, Washington, v. 5O, p. 1081-1083, 1999.

KING, D.E.; BUSHWICK, B. Beliefs and attitudes of hospitalized patients about faith healing and prayer. Journal of Family Practice, New York, v. 39, p.349352, 1994. 
KOENIG, H.G. Religious beliefs and practices of hospitalized medically ill older adults. International Journal of Geriatric Psychiatry, Chichester, v. 13, p. 213-224, 1998.

KOENIG, H.G., McCullough, M.E. \& Larson, D.B. (2001). Handbook of religion and health. New York: Oxford University Press, 2001.

KOENIG, H.G.. Spirituality in Patient Care: Why, How, When and What. Third Edition. Templeton Foundation Press, Philadelphia, 2013.

KOENIG, H.G., KING D.E., CARSON V.B. Handbook of religion and health, second edition. New York: Oxford University Press, 2012.

KRISTELLER, J.L., ZUMBRUN, C.S., SCHILLING, R.F. I would if I could: How oncologists and oncology nurses address spiritual distress in cancer patients.

Psycho-Oncology, New York, v. 8, p. 451-458, 1999.

LUCCHETTI, G. et al. Spiritist Psychiatric Hospitals in Brazil: Integration of Conventional Psychiatric Treatment and Spiritual Complementary Therapy. Cult Med Psychiatry, Dordrecht, v. 36, p. 124-135, $2012 \mathrm{a}$.

LUCCHETTI, G. et al. Exploring the acceptance of religious assistance among patients of a psychiatric hospital. International Journal of Social Psychiatry, London, v. 59, n. 4, p. $311-317,2012 b$.

MASTERS, K.S. et al. Religious orientation, aging, and blood pressure reactivity to interpersonal and cognitive stressors. Annals of Behavioral Medicine, Knoxville, v. 28, p. 171-178, 2004.

MESQUITA, A.C. et al. El bienestar espiritual y la prestación del cuidado espiritual en un equipo de enfermería - The spiritual well-being and the provision of spiritual care in a nursing staff. Index de Enfermaría, Granada, v. 23, n. 4, 2014.

MOADEL, A. et al. Seeking meaning and hope: Self-reported spiritual and existential needs among an ethnically-diverse cancer patient population. PsychoOncology, New York, v. 8, p. 378-385, 1999.

MOHR, S. et al. Toward an integration of spirituality and religiousness into the psychosocial dimension of schizophrenia. American Journal of Psychiatry, Washington, v. 163, p. 1952-1959, 2006.

MONOD, S.M. The Spiritual Distress Assessment Tool: An instrument to assess spiritual distress in hospitalised elderly persons. BMC Geriatric, 10: 88, 2010. Available at: http://www.biomedcentral.com/content/pdf/1471-2318-10-88.pdf. Acessed in October, 10th, 2015. 
MONTEIRO, A. C. M. et al. A atuação do enfermeiro junto à criança com câncer: cuidados paliativos /Nurses' work with children with cancer: palliative care. Rev enferm UERJ, Rio de Janeiro, v. 22, n. 6, p. 778-83, 2014.

NASCIMENTO, L.C. et al. Cuidado espiritual: componente essencial da prática da enfermeira pediátrica na oncologia / Cuidado espiritual: componente esencial de la práctica de la enfermera pediátrica en la oncologia. Acta Paulista de Enfermagem. São Paulo, v. 23, n. 3, 2010.

PAAL, P.; P.; HELO, Y.; FRICK, E. Spiritual Care Training Provided to Healthcare Professionals: A Systematic Review. J Pastoral Care Counsel. vol. 69, March 2015. p. 19-30.

PARGAMENT, K. The psychology of religion and coping: Theory, research, and practice. New York: Guilford Press, 1997.

PENHA, R. M. ; SILVA, M. J. P.. Meaning of spirituality for critical care nursing. Texto contexto - enferm., Porto, v. 21, n. 2, p. 260-268, 2012.

PESSINI L, BERTACHINI L. Novas perspectivas em cuidados paliativos: ética, geriatria, gerontologia, comunicação e espiritualidade. Mundo Saúde, São Paulo, v. 29, n.4, p. 491-509, 2005.

PHILLIPS, R.S., LAKIN, R. \& PARGAMENT, K.. Development and implementation of a spiritual issues psychoeducational group for those with serious mental illness. Community Mental Health Journal, New York, v. 38, p. 487-496, 2002.

PONTE, K. M. A. et al. Contribuição do cuidado clínico de enfermagem para o conforto psicoespiritual de mulheres com infarto agudo do miocárdio. Esc. Anna Nery, Rio de Janeiro, v. 16, n. 4, p. 666-673, 2012.

PROPST, L.R.; OSTROM, R.; WATKINS, P.; DEAN, T.; MASHBURN, D.. Comparative efficacy of religious and nonreligious cognitive-behavior therapy for the treatment of clinical depression in religious individuals. Journal of Consulting and Clinical Psychology, Arlington, v. 60, p. 94-103, 1992.

PUCHALSKI, C.M.; ROMER A.L.. Taking a Spiritual History Allows Clinicians to Understand Patients More Fully. Journal of Palliative Medicine, Larchmont, v. 3, p. 129-37, 2000.

PUCHALSKI, C.M.; LUNSFORD, B.; HARRIS, M.H. \& MILLER, T. Interdisciplinary spiritual care for seriously ill and dying patients: A collaborative model. Journal of Cancer, Sudbury, v. 12, p. 398 - 416, 2006. 
PUCHALSKY, C.M. et al. D. Improving the Quality of Spiritual Care as a Dimension of Palliative Care: The Report of the Consensus Conference. Journal of

Palliative Medicine, Larchmont, v. 12, n. 10, p. 885 - 904, 2009.

REED, P.G.. Preferences for spiritually related nursing interventions among terminally ill and non-terminally ill hospitalized adults and well adults. Applied Nursing Research, Philadelphia, v. 4, p. 122-128, 1991.

ROESE, A. A abordagem feminista do cuidado espiritual e psicoterapêutico.

Estudos Teológicos, Coimbra, v. 50, p.288 - 305, 2010.

SATHLER-ROSA, R. Cuidado espiritual como fator de integralidade (saúde) do Ser: funções históricas do cuidado na tradição judaico-cristã. Rev. Pistis Prax., Teol. Pastor., Curitiba, v. 6, n. 1, jan./abr. 2014.

SCHMIDT, T.; ADAMI, S. Depression und Glaube - eine qualitative Studie an der Universität Freiburg. Diplomarbeiten, Wien, 2008.

SILVA, R. S.; CAMPOS, A. E. R.; PEREIRA, A. Caring for the patient in the process of dying at the Intensive Care Unit. Rev. Esc. Enferm., São Paulo, v. 45, n. 3, p. 738-744, 2011.

SOUZA, R. C.; CALDAS, N.M. Os sentidos da relação entre saúde mental e religiosidade para profissionais de saúde na família em Ilhéus - Bahia, Ciência, Cuidado e Saúde. Maringá-PR, v. 8, n. 3, p.460-468, 2009.

SOUZA, J.R, MAFTUM, M.A., MAZZA, V.A. The nursing care in the spiritual dimension: undergraduates' experience / O cuidado de enfermagem na dimensão espiritual: vivência do estudante de graduação. Online Brazilian Journal of Nursing . Niterói (RJ), v. 8, n. 1, 2009. Available from: <http://www.objnursing.uff.br/index.php/nursing/article/view/j.16764285.2009.2127/466>. Access: 2015 Oct 31.

SULMASY, D.P. et al. The quality of mercy: Caring for patients with do not resuscitate orders. Journal of the American Medical Association, Chicago, v. 267, p. 682-686, 1992.

SULMASY, D.P.. Addressing the religious and spiritual needs of dying patients. Western Journal of Medicine, San Francisco, v. 175, n. 4, p. 251-254, 2001.

SULMASY, D. P. A biopsychosocial-spiritual model for the care of patients at the end of life. Gerontologist, Cary, v. 42, n. 3, p. 24-33, 2002. 
TEPPER, L. et al. The prevalence of religious coping among persons with persistent mental illness. Psychiatric Services, Washington, v. 52, n. 5, p. 660-665, 2001.

WONG-MCDONALD, A. Spirituality and psychosocial rehabilitation: empowering persons with serious psychiatric disabilities at an inner-city community program. Psychiatric Rehabilitation Journal, Boston, v. 30, p. 295-300, 2007. 